Article

\title{
The Sustainable Use of Water Resources: A Technical Support for Planning. A Case Study
}

\section{Vincenzo Torretta}

Department of Biotechnologies and Life Sciences, Insubria University, Via G.B. Vico 46, Varese I-21100, Italy; E-Mail: vincenzo.torretta@uninsubria.it; Tel.: +39-0332-218-782;

Fax: +39-0332-218-779

External Editor: Marc A. Rosen

Received: 16 July 2014; in revised form: 7 November 2014 / Accepted: 7 November 2014 / Published: 14 November 2014

\begin{abstract}
The paper presents both the structure and application of a Decision Support System (DSS) for an important river in Brazil — along with the sustainable management of its watershed. This DSS assesses both surface-water quality and riverine microhabitats in terms of future scenarios, taking into account regulation limits and appropriate quality indexes. Our future scenarios consider: (a) population and climate change trends; (b) upgrade of sewage systems and wastewater treatment plants; and (c) withdrawal management from rivers and reservoirs. We use some main types of interrelated models, which can simulate different aspects of the responses of a basin, with respect to different modes of use of the water resource. In particular, the surface-water quality models simulate total phosphorus, BOD, dissolved oxygen concentration and thermo-tolerant coliform bacteria pollution. The riverine microhabitat models apply habitat suitability indexes of autochthonous fish species considering water depth, velocity, bottom substrate and dissolved oxygen. Both models are based on hydrologic and hydraulic models results and both were calibrated using discharge and water quality measurements collected over a 1.5 -year monitoring period. Our pre- and post-processing are based on common spreadsheets and the output data are spatially analyzed using GIS software. Examples are also shown of how the DSS can contribute to developing a sustainable use of the basin resources, including a reservoir used to supply drinking water to the capital city (Salvador da Bahia).
\end{abstract}

Keywords: decision support system; modeling; river basin management plan; water quality 


\section{Introduction}

The sustainable use of land and its resources is an important issue particularly in terms of the sustainable use of water resources. Any technological tools effectively help technicians to plan the use of resources, and are therefore extremely important. The conservation and sustainable use of water, and how the exploitation of this vital resource is planned, is critical. Technological tools that can support the decision-maker have become increasingly important. River basin governance requires complex decision making regarding regulations, population distribution, land use and the availability of resources. Local planning systems involve mitigating the impact of human activity on the environment.

Decision-makers (DMs) usually have to balance private and public stakeholder interests through (a) a multi-hazard approach; (b) taking into account the spatial dimension of the problem; and (c) considering basin vulnerability. They therefore need appropriate decision support tools capable of integrating the required information.

A decision support system (DSS) is a specific class of computerized information systems, which assists people in making decisions based on data that are gathered from a wide range of sources. DSS applications are not single information sources, like a database, a model or a program that graphically represents results, but rather the combination of integrated sources. The structure and design of a DSS varies according to the decision-making requirements as well as the decision-maker's skills [1,2].

Many DSSs have been developed managing of river basins [3-8], however they do not solve all the problems, in the sense that they are often not able to provide all the answers related to the assumption of different scenarios of planning. One common limitation of a DSS is the excessive level of complexity with respect to the knowledge of the operators and stakeholders [9]. This is a significant problem, because it prevents stakeholders from being fully involved in decision making. The involvement of stakeholders has a direct impact on the sustainability of decisions that are made as a result of the modeling intervention. In addition, for this reason, DSS tools must be flexible in order to verify in a rapid way, the effectiveness of stakeholder suggestions.

The Pojuca River (in Brazilian-Portuguese Rio Pojuca") is about $200 \mathrm{~km}$ long and flows from west to east through Recôncavo Norte, a region of Bahia State, Brazil (Figure 1). The source is located in a semi-arid region, while the mouth is in the Atlantic Ocean near the tourist resort of Praia do Forte.

The basin (4771 $\mathrm{km}^{2}$ area) is currently undergoing rapid urban growth. In 2010, the population density was about 272 inhab $\mathrm{km}^{-2}$ [10] with all the problems related to significant pollution pressure and with urban and industrial development. This recent and rapid evolution has resulted in the need to address several issues related to the environmental protection and the sustainable development of the area. This means new problems and a new approach to tackle effectively the waste production and treatment [11], as well as the energy recovery from waste (starting almost from zero, as in all developing areas) [12]. However, this also entails controlling the emission load into the atmosphere and into the water, where important new pollutants now appear (e.g., PAHs, micropollutants) with all the related environmental problems [13]. 
Figure 1. Location and overview of the Pojuca River basin (included the position of the Itapecirica reservoir).
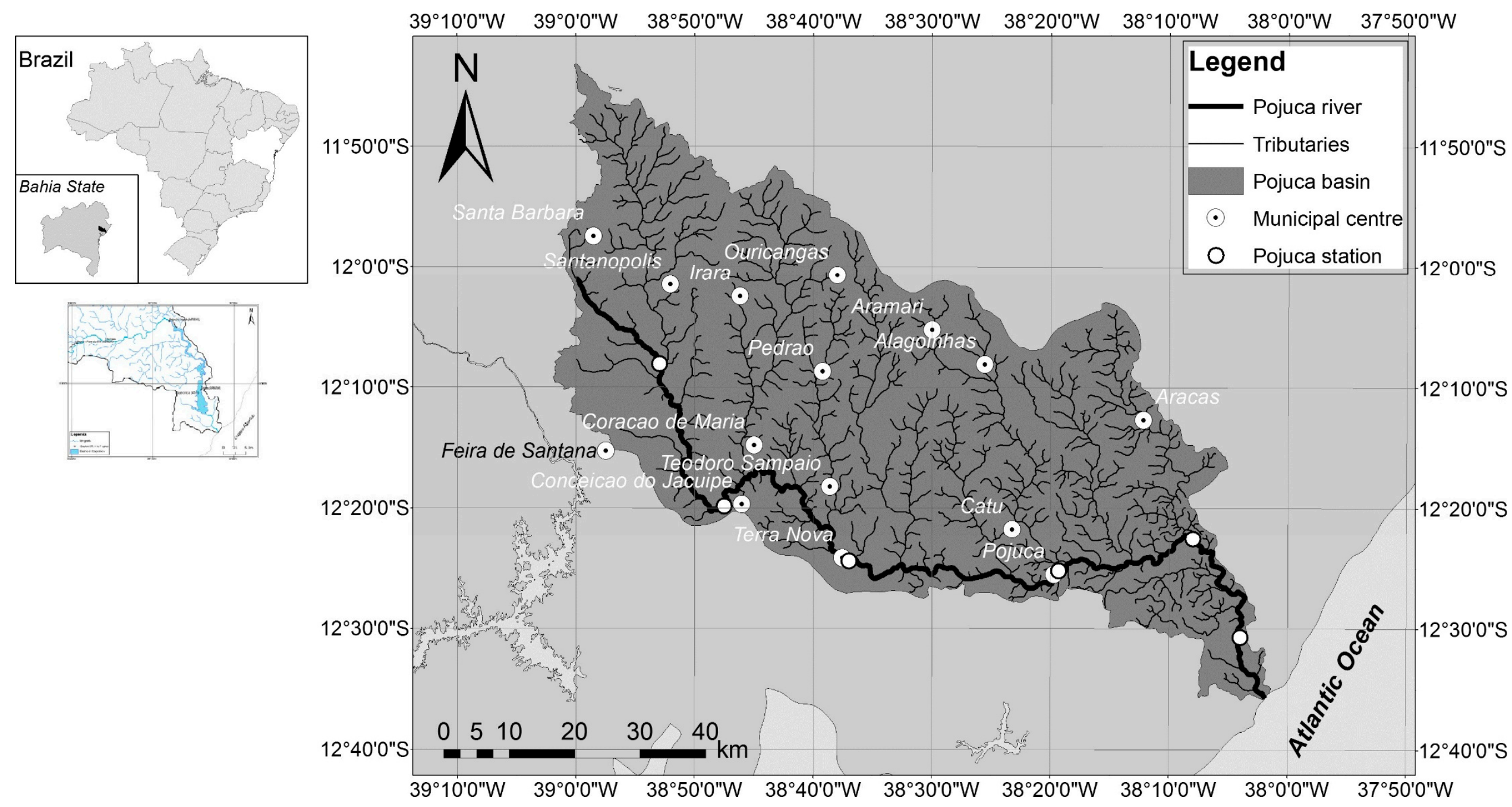
Over the past two decades there has been a significant increase both in industrial activities and in traditional farming practices. At the same time, eco-tourism along the oceanic coast near the Pojuca estuary has been developed, and such zones host a protected egg-laying site for loggerhead sea turtles (Caretta caretta). In recent years, the first but significant symptoms of water pollution have appeared, affecting both the economic activities related to tourism and the ecosystem (especially the turtle community) [14].

This situation has deteriorated further due to the fact that the annual rainfall and the average flow, have shown a decrease in water availability (Figure 2). In addition, a preliminary project was set up for the construction of a reservoir ("Itapecirica Lake"), located near the mouth of the river, in order to provide Salvador da Bahia (the capital of the state of Bahia), metropolitan area with drinking water [10].

Figure 2. Time series (1963-2011) of (a) annual rainfall and (b) average annual Pojuca River discharge near the estuary.

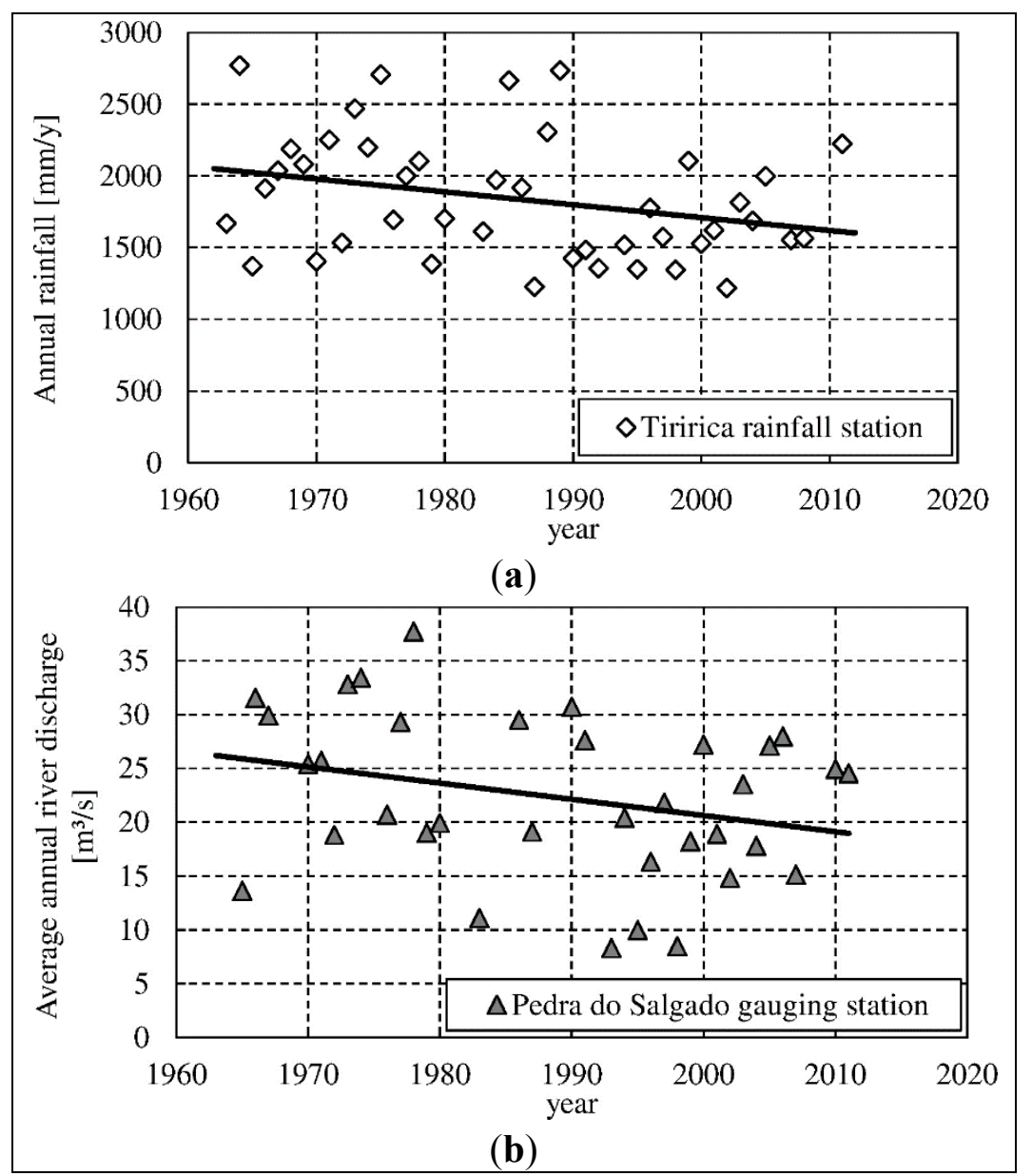

Recently, a two-year international cooperation project between Italy and Brazil aimed at implementing a sustainable river basin management plan (RBMP) was set up for the Pojuca River. The aim was to protect the quality of surface water and river ecosystems, without compromising the social and economic growth of the whole basin.

The RBMP has been developed in such a way as to promote the best guidelines and policy choices, considering climate change and social and economic development (the so-called "pressure", according to the OECD Pressure-State-Response framework adopted in the State of Bahia) [15]. 
This paper presents the main features and possible applications of the Rio Pojuca-DSS (RP-DSS): a DSS based on a simple and robust dynamic model, which is able to simulate qualitative and quantitative aspects of surface waters and to assess the river microhabitat, as briefly described in the next section. This follows a previous work [10], which investigated the sources of pollution of the basin, the sewage systems and the status of wastewater treatment plants (WWTPs).

Brazilian regulations [16] determine who should participate in the decision-making process for the river basin management plans (RBMPs), and in particular the so-called basin committees. More importantly, the aim of the RP-DSS was be "user-friendly", thus enabling to the widest possible dissemination of information among all the components of the basin committees.

The project for development of the RP-DSS follows the principles of the Instream Flow Incremental Methodology (IFIM) [17], which was developed to improve the assessment of possible management alternatives.

\section{Materials and Methods}

A detailed investigation into the environmental, social and economic aspects of the basin ("Pressure", "State" and the current "Responses") was conducted using databases, digital mapping and field surveys, in order to identify the problems and create a diagram of the basin. All the information collected on the territory was shown in digital mapping, highlighting the critical conditions that emerged during the monitoring and field visits and from the surveys. This focused on several items: demography, land use, economic activity, meteorology, hydrology, hydraulics, water demand, withdrawals and discharges, sewer systems and WWTP status. Details on the input data required by the model are listed in Table 1.

Table 1. Overview of main inputs, together with their source, and outputs required by the models composing the RP-DSS.

\begin{tabular}{llll}
\hline \multicolumn{1}{c}{ Model } & \multicolumn{1}{c}{ Main Inputs } & Source * & \multicolumn{1}{c}{ Main Outputs } \\
\hline & Pollutant concentrations & WQM & $\begin{array}{l}\text { Brazilian regulation limits } \\
\text { according to water resource use: } \\
\text { 1. Compliancy } \\
\text { 2. Surplus annual frequency }\end{array}$ \\
\cline { 2 - 4 } Assessment (ASM) & Pollutant concentrations & WQM & $\begin{array}{l}\text { Partial WQI time series } \\
\text { Reservoir trophic state based on } \\
\text { total phosphorus concentration }\end{array}$ \\
\cline { 2 - 4 } & Water temperature & MHM & $\begin{array}{l}\text { Daily Physical HSI (following } \\
\text { life-stages and reproductive period) }\end{array}$ \\
\cline { 2 - 4 } & River discharge time series & HLM & $\begin{array}{l}\text { Daily Composite HSI (CHSI, } \\
\text { following life-stages and } \\
\text { reproductive period) }\end{array}$ \\
\cline { 2 - 4 } & Habitat Suitability Curves & ASM & \\
\cline { 2 - 4 } & Daily Physical HSI & S\&R & \\
\cline { 2 - 4 } & DO suitability graph & WQM & \\
\cline { 2 - 4 } & DO concentration & & \\
\hline
\end{tabular}


Table 1. Cont.

\begin{tabular}{|c|c|c|c|}
\hline Model & Main Inputs & Source * & Main Outputs \\
\hline \multirow{5}{*}{$\begin{array}{l}\text { Riverine physical } \\
\text { microhabitat } \\
\text { (MHM) }\end{array}$} & Cross-section shape and slope & $\mathrm{S} \& \mathrm{R}$ & $\begin{array}{l}\text { Reference species Physical Habitat } \\
\text { Suitability Curves (relate available } \\
\text { usable bottom length with } \\
\text { cross-section discharge) }\end{array}$ \\
\hline & Steady-state stage-discharge curves & & \\
\hline & Bottom substrate characteristics & & \\
\hline & $\begin{array}{l}\text { Reference species physical habitat } \\
\text { suitability graphs }\end{array}$ & & \\
\hline & Reference species reproduction periods & & \\
\hline \multirow{5}{*}{$\begin{array}{l}\text { Surface Water- } \\
\text { quality (WQM) }\end{array}$} & Pollutant loads & PLM & Pollutant concentrations time series \\
\hline & Water temperature & WQM & \\
\hline & Travel time & HDM & \\
\hline & River velocity and depth & & \\
\hline & Reservoir volume & & \\
\hline \multirow{4}{*}{ Hydraulic (HDM) } & Cross-section morphology & S\&R & Water depth, velocity and travel time \\
\hline & Stage-Discharge curve & & \\
\hline & Hydrography (river length) & & \\
\hline & River Discharge & HLM & \\
\hline \multirow{5}{*}{ Hydrologic (HLM) } & Hydrologic data & $\mathrm{S} \& \mathrm{R}$ & $\begin{array}{l}\text { River discharge } \\
\text { Reservoir volume }\end{array}$ \\
\hline & Averaged meteorological data $* *$ & S\&R & \\
\hline & Water withdrawal & $\mathrm{S} \& \mathrm{R}+\mathrm{R}$ & \\
\hline & Reservoir presence & $\mathrm{S} \& \mathrm{R}+\mathrm{R}$ & \\
\hline & Reservoir regulation & $\mathrm{S} \& \mathrm{R}+\mathrm{R}$ & \\
\hline \multirow{5}{*}{$\begin{array}{l}\text { Pollutant Load } \\
\text { (PLM) }\end{array}$} & Land use (urbanized areas) & $\mathrm{S} \& \mathrm{R}+\mathrm{R}$ & Pollutant point loads estimation \\
\hline & Population (urban and rural) trends & & \\
\hline & Factories typology and location & & \\
\hline & Sewage systems population coverage & & \\
\hline & WWTPs removal efficiencies & & \\
\hline
\end{tabular}

* Acronyms are described in the first column; S\&R: Surveys and Research activities. R: Responses and actions defined by users. ** Air temperature, wind velocity, relative humidity and atmospheric pressure.

Analysis of spatial data using GIS software (ESRI ArcGIS ${ }^{\circledR}$ Desktop 9.1-ESRI's distributor for Italy: ESRI Italy, Rome), helps to create the working basis of the DSS, which in our case is a schematic diagram of the river together with its principal tributaries, the locations of main discharge pollutant points (sewage systems and WWTPs), and withdrawals.

A volume-elevation curve and an area-elevation curve were created for the Itapecirica reservoir project by processing digital maps with GIS software and Golden Software Surfer ${ }^{\circledR}$ (Golden Software LCC, Golden, CO, USA).

In addition, a 1.5-year water quality monitoring campaign was carried out. Monitoring station locations involved the following criteria: (a) the station was sufficiently downstream respect to the position of pollution discharges in order to achieve a reasonable complete mixing situation and (b) it had 
a measure of river flow (hydraulic station). Thus, six monitoring stations were downstream of the main towns on the Pojuca River and near the discharge gauging stations (Figure 1).

Local ichthyologists and biologists carried out riverine ecosystem surveys in order to (a) detect reference cross sections representative of all the watercourse habitats; (b) detect Pojuca reference species; (c) define their suitability graphs.

Representative sites of the whole Pojuca basin aquatic ecosystem were selected close to the gauging stations.

Based on previous researches conducted in the study area, ichthyologists suggested two reference species: Parotocinclus bahiensis [18] for the upstream section of the river, and Characidium [19] for the downstream section.

A suitability graph [20] relates the considered physical or chemical parameter value with the suitability to life of reference species, using a value ranging between 0 and 1 , which is called the Suitability Index $(S I)$. Physical suitability graphs of the Pojuca reference species are shown in Figure 3a,b respectively. Regarding dissolved oxygen concentrations, ichthyologists chose the Semotilus atromaculatus suitability graph [20] because of its similarity with the Pojuca reference species (Figure 3c).

Figure 3. Physical habitat suitability graphs of (a) Parotocinclus bahiensis and (b) Characidium for juvenile and adult-reproductive life-stages concerning water depth (D), velocity (V) and bottom substrate $(\mathrm{S})$.
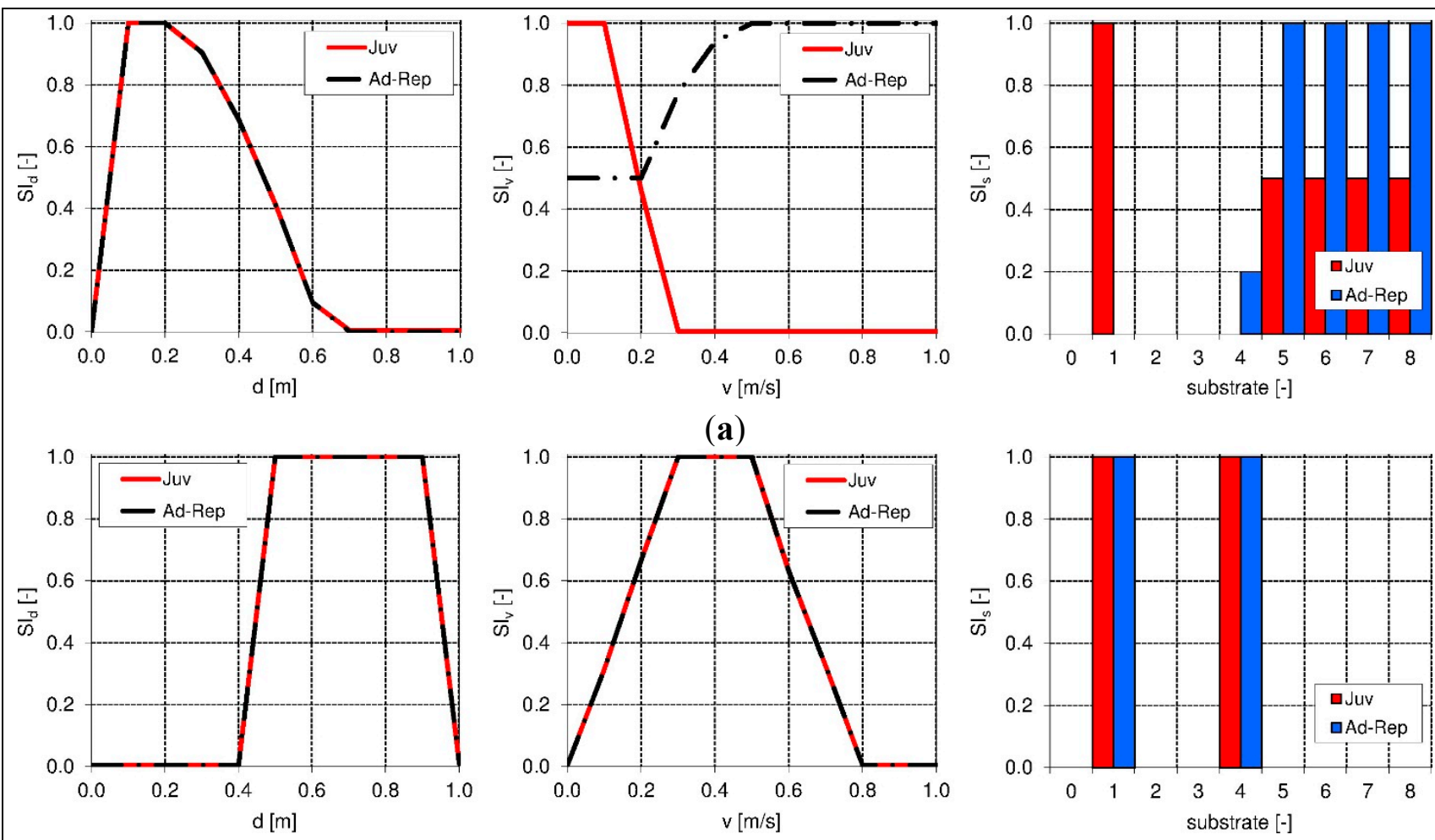

(a)
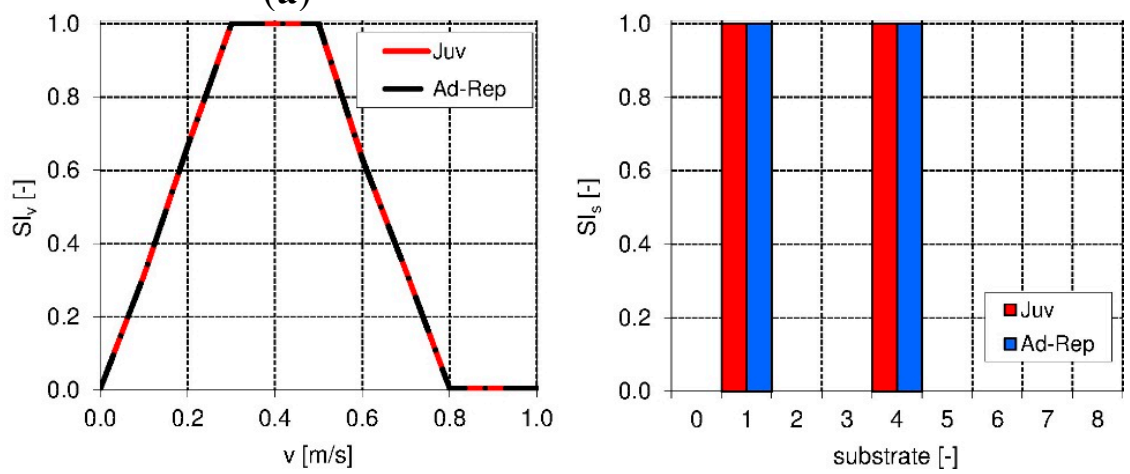

(b) 


\subsection{DSS Structure}

\subsubsection{General Description}

The RP-DDS is made up of five interconnected deterministic models (Figure 4). The model directly usable by stakeholders is the assessment model while the remaining models work as driving components. The main input — output data required by the models are shown in Table 1.

Figure 4. Structure of the RP-DSS: relationships between models (dotted line blocks) and main scenario management inputs (continuous line blocks); CHSI (composite habitat suitability index) and HIS (Habitat Suitability Index).

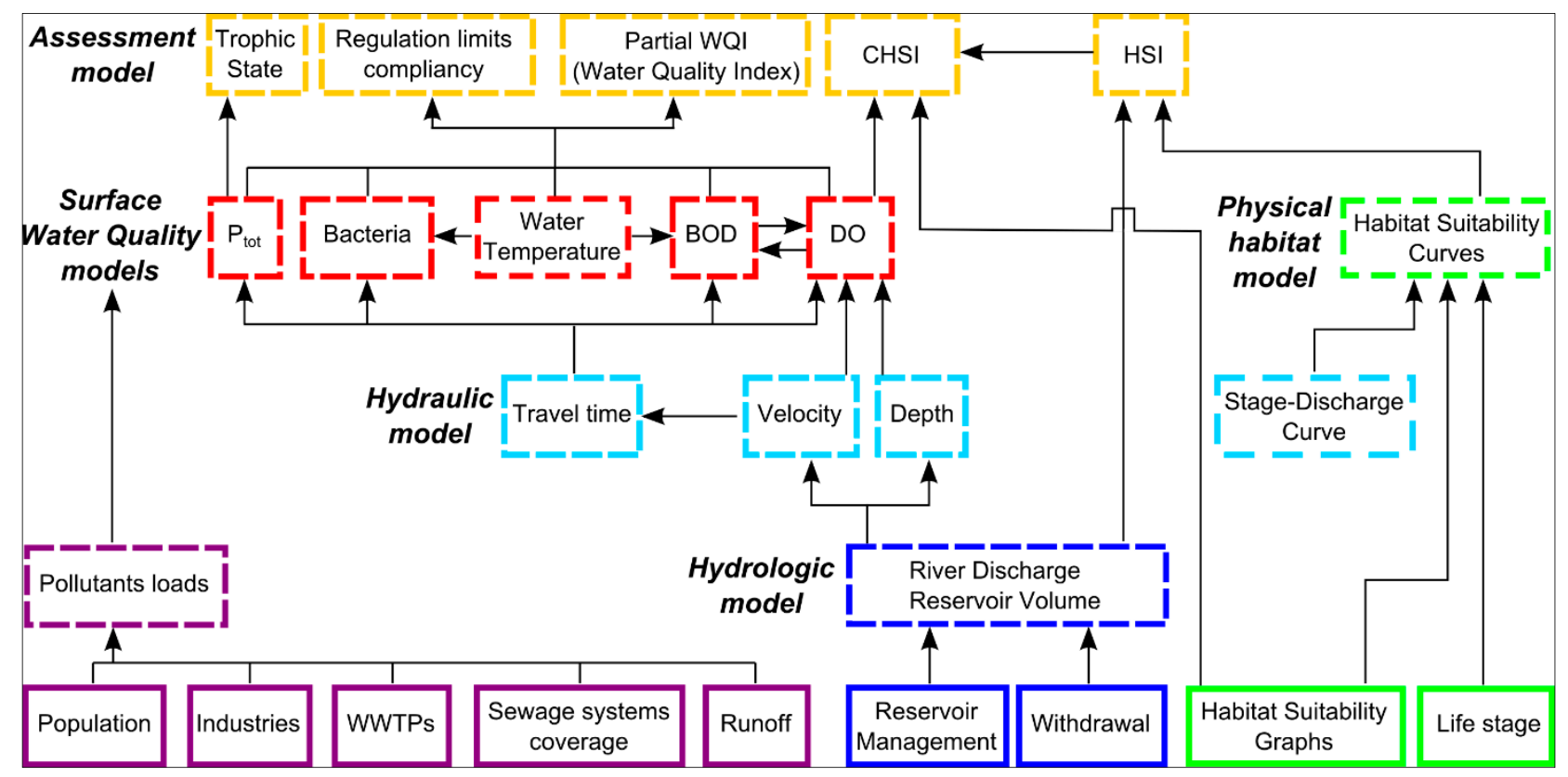

RP-DSS development was influenced by the scarcity of available data. Only six points along the Pojuca basin were evaluated (this means that the system is implementable and improved by increasing the available data sets for calibration). Data output had a daily frequency.

\subsubsection{Hydrologic Model}

The hydrologic model (HLM) simulates river discharge considering tributaries, water withdrawals, and the presence and management of reservoirs.

In order to determine the average discharge $(Q)$, a regression model based on all the data recorded by the gauging stations located inside the basin was adopted in accordance with the suggestions provided by the applied hydrology studies [21]. The gauging station with the longest time series was set as the "reference". Monthly mean discharges at each station are calculated and correlated with the corresponding reference station monthly mean discharge. Hence, the hydrologic model simulates the flow rate at the gauging stations using the hydrograph of the reference station. The flow rate can thus be managed by considering both the reference station average annual discharge and hydrograph shape.

A classical water balance equation was applied to a reservoir [21], considering the losses, such as infiltration and evaporation. Infiltration effects are neglected, while evaporation is computed using 
a combined aerodynamic and energy balance method [19] and reservoir surface area, obtained from the reservoir area-elevation curve.

\subsubsection{Hydraulic Model}

A monodimensional hydraulic model (HDM) was adopted. In HDM, mean velocity $(V)$ and mean water depth $(D)$ are computed at each station using discharge and steady state rating curves [21]. The $i$-th stretch average travel time was estimated using the method described in Chapra et al. (2008) [22].

\subsubsection{Pollutant Load Model}

The Pollutant load model (PLM) computes civil and industrial point source loads $(L)$ of total phosphorus, thermo-tolerant coliforms and biochemical oxygen demand (BOD). The PLM uses the following formula:

$$
\begin{gathered}
\mathrm{L}(\mathrm{t})=\mathrm{L}_{\text {civil }}(\mathrm{t})+\mathrm{L}_{\text {runoff }}(\mathrm{t})+\mathrm{L}_{\text {industrial }}(\mathrm{t}) \\
=\mathrm{HSL}\left(\mathrm{n}_{\text {urban }}(\mathrm{t}) \mathrm{c}_{\mathrm{ss}}\right)\left[\mathrm{c}_{\mathrm{wwtp}} \mathrm{RE}_{\text {wwtp }}+\left(1-\mathrm{c}_{\mathrm{wwtp}}\right)\right]+\mathrm{L}_{\text {area }} / 365 \text { Aurban }+\mathrm{Lindustrial}(\mathrm{t})
\end{gathered}
$$

where $H S L$ is the daily human specific load; $n_{u r b a n}(t)$ is the urban population in the simulated year; $c_{s s}$ is the sewage system coverage (percentage of the urban population); $c_{w w t p}$ is the WWTP coverage (percentage of $c_{s s}$ ); $R E_{w w t p}$ is the WWTP removal efficiency concerning the considered pollutant; $L_{a r e a}$ is the annual pollutant areal load for residential area runoff, and $A_{u r b a n}$ is the residential area.

\subsubsection{Water Quality Models}

Three simplified monodimensional (1-D) models, based on complete mixing, were developed [22]. The conservative pollution model considers the chemical dispersion due only to dilution and advection [23]. The model was used to estimate the total phosphorus concentration, which was then used to assess the risk of eutrophication in the Itapecirica reservoir.

According to CONAMA (2005) [24], the bacteriological pollution model considers thermo-tolerant coliforms. A classical decay law was implemented [23].

The BOD-DO model considers the classical Streeter and Phelps model. Atmospheric reaeration were taken into account using O'Connor's formula [23].

Water temperature was simulated using a cosine function of time whose parameters are able to best fit (using the least squares method) all the available field measurements.

Regarding the reservoir module, the basin was considered as completely mixed. DO concentration downstream the reservoir is influenced by dam spillway and is described using the Hydroscience formulation [23]. The CEPIS method [25] for the evaluation of tropical reservoir trophic state was also implemented.

The WQM time step is $0.25 \mathrm{~d}$ while an Euler explicit integration method was adopted [23].

\subsubsection{Riverine Physical Microhabitat Model}

The Riverine physical microhabitat model (MHM) assesses the level of instream habitat suitability to life of the reference species. MHM considers the variations of three physical parameters $(\mathrm{V}, \mathrm{D}$ and 
substrate bottom, S) with discharge by applying the "transect method" [26]. The model follows the PHABSIM method [27] and computes Weighted Usable Length graphs for each physical parameter $P(W U L P)$ :

$$
W U L_{P i j k}(Q)=\sum_{l=0}^{w_{i}} S I_{P j k}\left(P_{i}\right) \Delta l
$$

where $i$ is the river cross-section, $j$ is the reference species, $k$ is the reference species life-stage, $w$ is the cross-section width, and $\Delta l$ is a portion of the cross-section bottom length.

\subsubsection{Assessment Model}

The assessment model (ASM) evaluates and compares all the outcomes of the developed scenarios through the computation of (a) the frequency with which regulation limits are exceeded and (b) daily index values.

ASM evaluates the compliance of Pojuca water with Brazilian regulation limits for drinking water withdrawal and bathing in lotic and lentic environments [24].

ASM also computes a partial Brazilian water quality index (IQA) [28], which considers total phosphorus $\left(\mathrm{P}_{\text {tot }}\right), \mathrm{BOD}_{5}, \mathrm{DO}$, temperature and thermotolerant coliforms at each monitoring station.

Concerning the riverine ecosystem, ASM calculates:

a. DO Suitability Index, $S I_{D O}(t)$, using DO concentration time series, $D O_{i}(t)$, and the DO suitability graph (Figure 3c).

b. Physical Habitat Suitability Index, $H S I_{i j k}(t)$, for both reference species and life-stages, following USGS (2001) [27]; a multiplicative weighting method between single WULPijk was adopted $[19,26]$ :

$$
\operatorname{HSI}_{P i j k}(t)=W U L_{P i j k}(Q(t))
$$

c. Composite Habitat Suitability Index, $\operatorname{CHSI}_{P i j k}(t)$, for riverine references species considering chemical and physical issues:

$$
\operatorname{CHSI}_{i j k}(t)=H S I_{i j k}(t) S I_{D O i}(t)
$$

ASM considers the spawning period and alerts the user with a message if the habitat is not suitable.

\subsection{8. "User-Friendly" Programming Language and User Interfaces}

Microsoft Excel ${ }^{\circledR}$ (Microsft-Italia, Milan, Italy) was used to create both input and output interfaces, while HPS Stella ${ }^{\circledR}$ (v.7.0.3) visual programming language was used to develop the models. The models are composed of a series of cascade connected standard modules (for an example, see Figure 5c); which facilitates subsequent use with other river basins.

Graphical interfaces are in Brazilian Portuguese to facilitate stakeholder comprehension (Figure 5).

A series of seminars regarding the use and development of the RP-DSS were organized at the end of the project in order to involve stakeholders in the use of tools.

Model output data are exportable using a GIS for any subsequent analysis. 
Figure 5. Snapshots from the RP-DSS: (a) Excel $^{\circledR}$ (Microsft-Italia, Milan, Italy) input interface; (b) Stella ${ }^{\circledR}$ (Isee Systems, Lebanon, NH, USA) microhabitat model interface; and (c) Stella ${ }^{\circledR}$ visual programming language (view of a BOD-DO module).

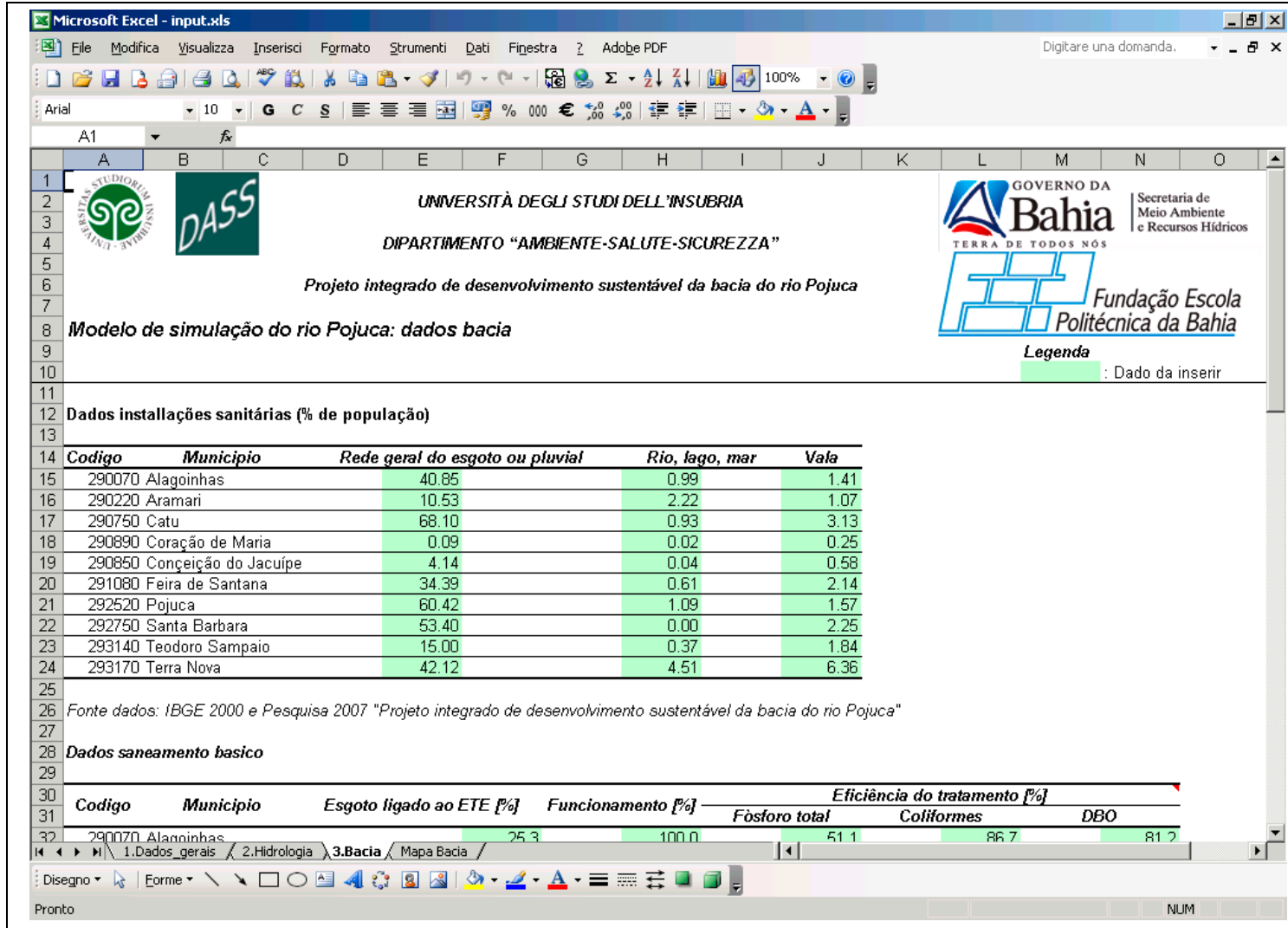

(a)

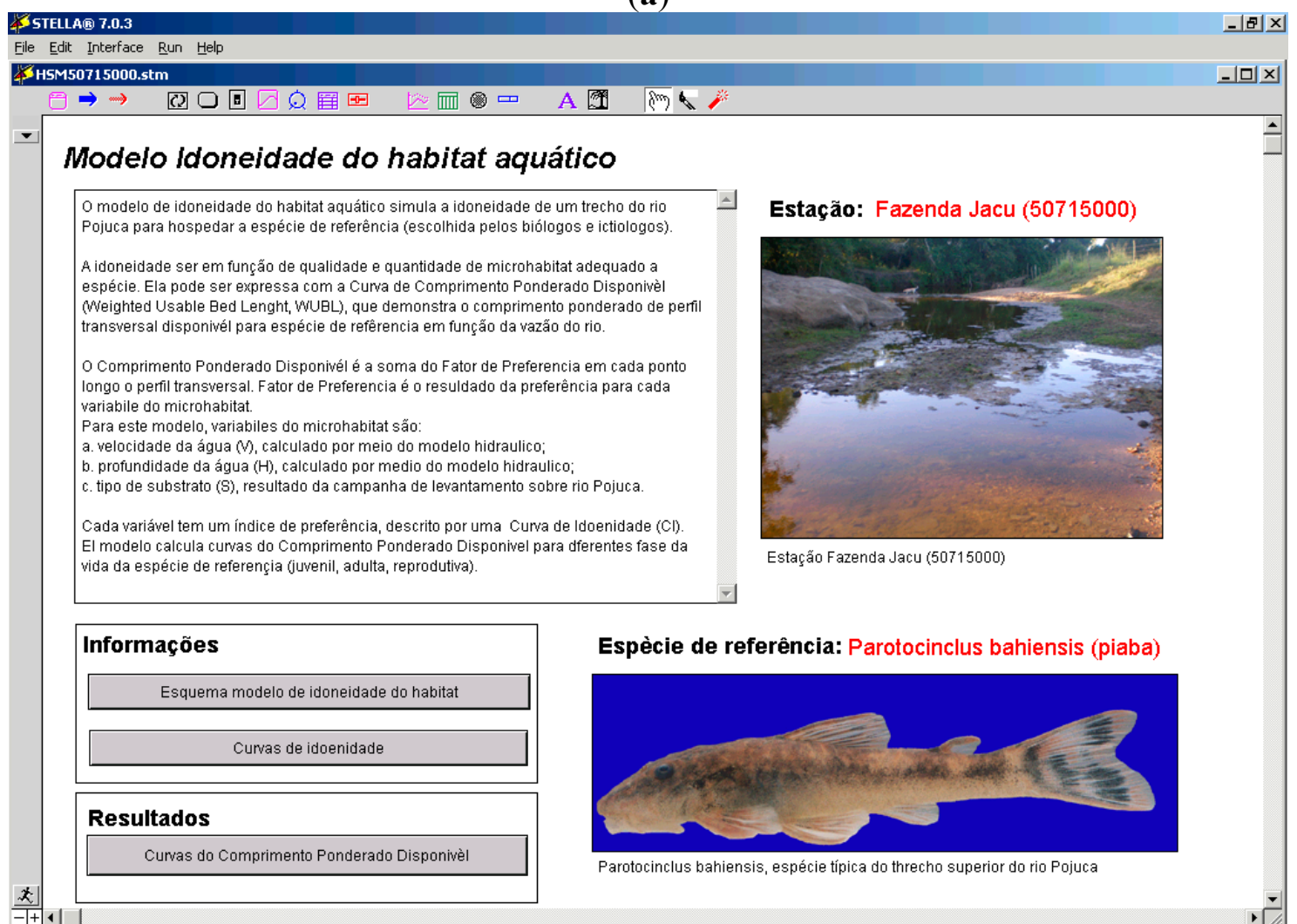

(b) 
Figure 5. Cont.

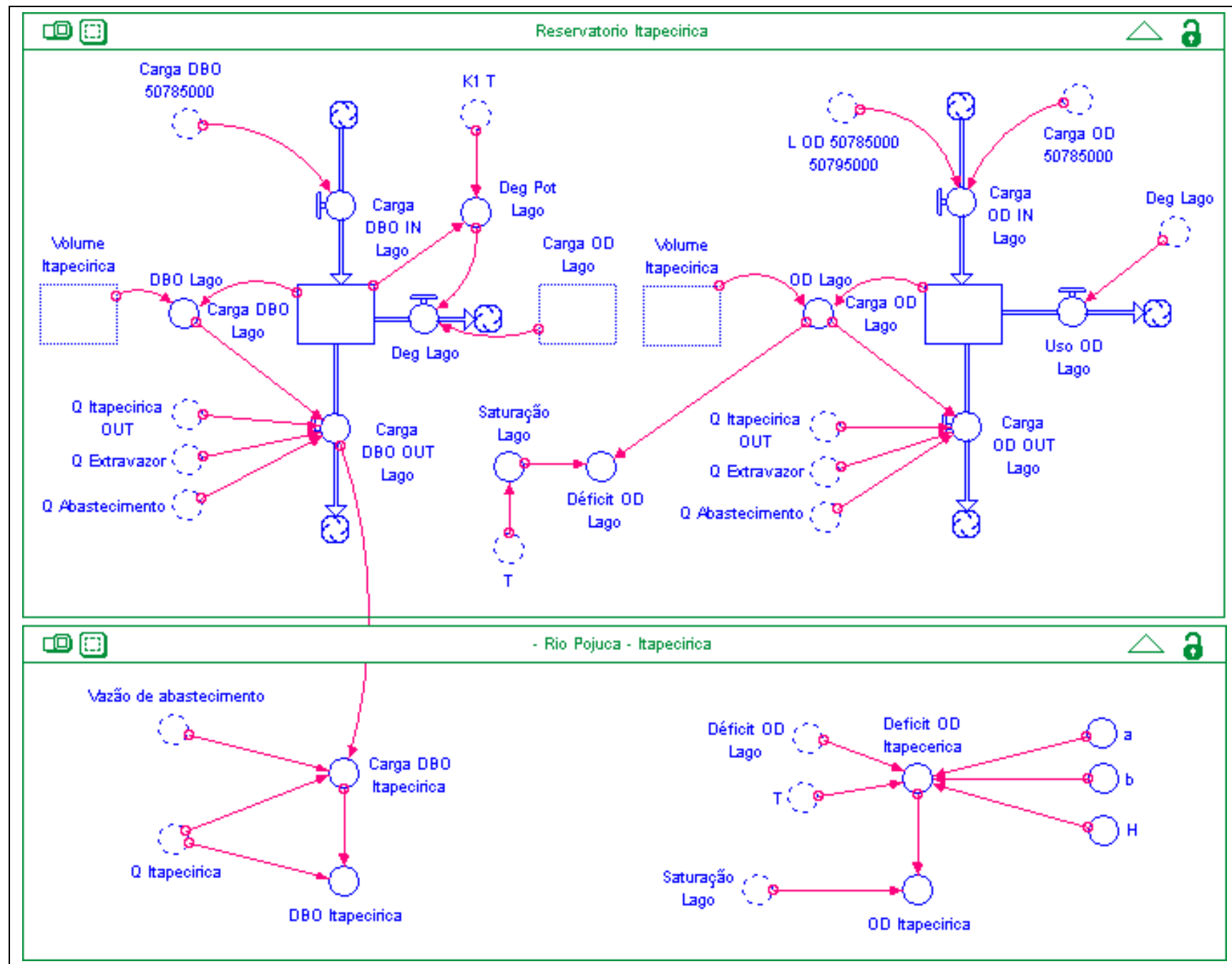

(c)

\subsection{Model Calibration and Validation}

Standard Brazilian loading values for human discharge and residential area runoff were used (Table 2).

Table 2. Daily human specific and annual pollutant areal runoff loadings adopted in the RP-DSS.

\begin{tabular}{cccccc}
\hline Parameter & Unit & Ptot & BOD & $\begin{array}{c}\text { Thermo-Tolerant } \\
\text { Coliforms }\end{array}$ & Source \\
\hline $\begin{array}{c}\text { Daily human specific loading } \\
\text { Annual pollutant area runoff loading }\end{array}$ & $\begin{array}{c}\mathrm{kg} \cdot \mathrm{inhab}^{-1} \cdot \mathrm{day}^{-1} \\
\mathrm{~kg} \cdot \mathrm{ha}^{-1} \cdot \mathrm{year}^{-1}\end{array}$ & 0.001 & 0.050 & $10^{9}$ & {$[29]$} \\
\hline
\end{tabular}

A total of 32 discharge and 132 water quality monitoring data were used to calibrate and validate HDM and WQMs. All the parameters from the calibration procedure are listed in Table 3. 
Table 3. WQM parameters found using the calibration procedure.

\begin{tabular}{ccc}
\hline Parameter & Unit & Adopted Value \\
\hline Bacteria decay rate at $20^{\circ} \mathrm{C}\left(\mathrm{K}_{\mathrm{B} 20}\right)$ & day $^{-1}$ & 1.5 \\
Oxidation rate of the carbonaceous material at $20{ }^{\circ} \mathrm{C}\left(\mathrm{K}_{120}\right)$ & day $^{-1}$ & 0.26 \\
DO concentration of non-polluted tributaries & $\%$ DO saturation & 80 \\
\hline
\end{tabular}

The table highlights that all the parameters are within the literature values [23,29]. An example of a comparison between simulation and monitoring data is shown in Figure 6.

Figure 6. Example of comparison between some numerical and monitoring results at the reference monitoring station: (a) discharge; (b) thermo-tolerant coliforms; (c) BOD (grey) and DO (black) concentrations.

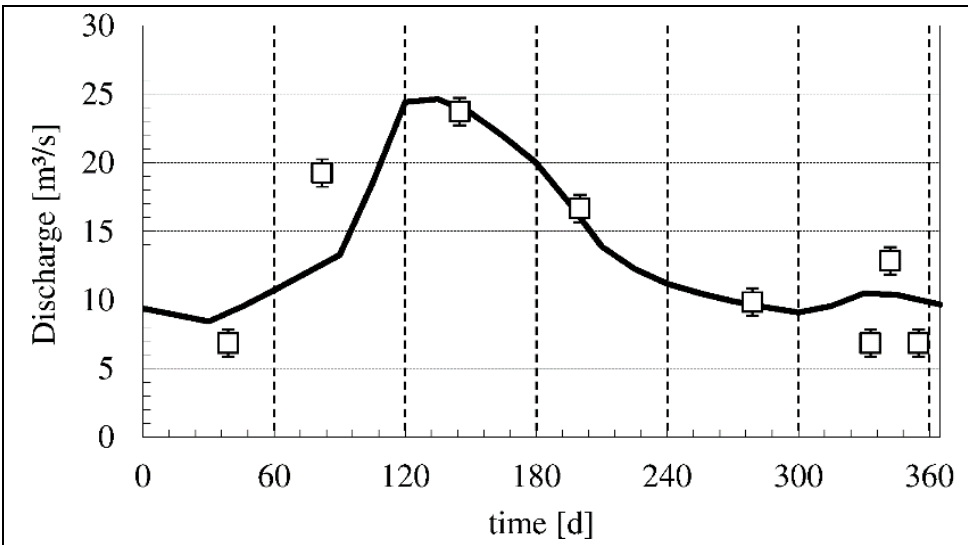

(a)

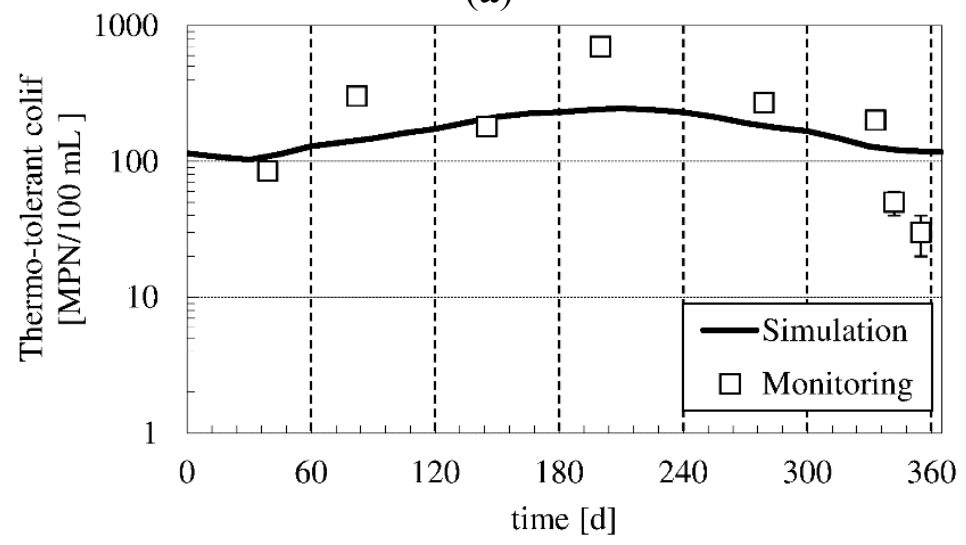

(b)

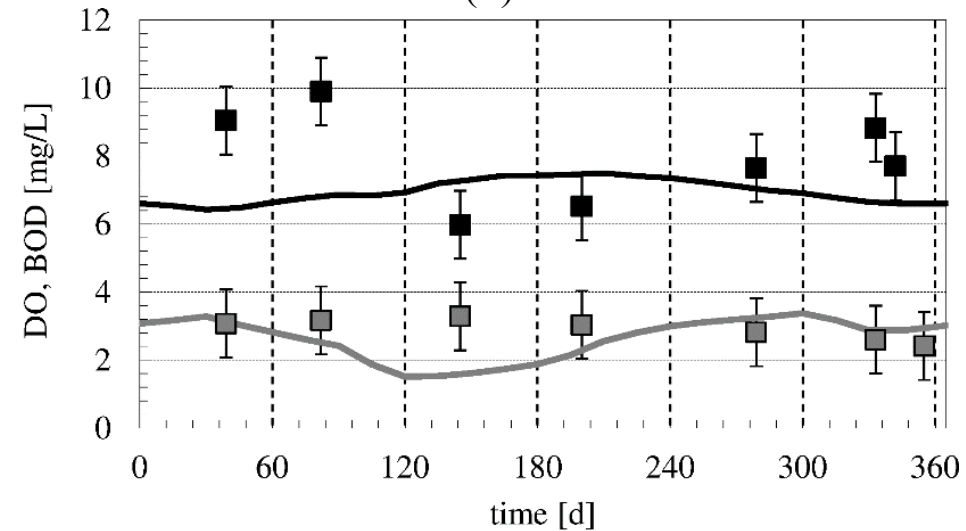

(c) 
Numerical results fit the measured data moderately well. Major problems occurred in monitoring and modeling operations at the upstream stations because of lack of discharge (in fact in the upstream stretch of the river, often the natural flows are small and most of the flow is constituted by rather variable discharges).

\section{Results and Discussion}

This section describes a number of possible applications of the RP-DSS. Several alternative future scenarios are compared, taking into account the climate change, the population growth and the withdrawal of water for supplying water to Salvador.

The year of the simulation was set to 2022 in order to provide useful predictions for new designs or upgrades of infrastructures, such as sewer systems or WWTPs.

\subsection{Impacts on Water Quality and Possible Technological Responses}

The first simulation was Scenario 0 (S0), which does not consider any kind of intervention to the infrastructures. The results of WQMs for Ptot, BOD and DO are described, respectively, in Figure 7a,b. Note that all the results are shown as percentage differences compared to the limits set by Brazilian standards for the use of drinking water (Class II) [24]. Maps also depict the daily municipal pollution loads.

Figure 7. Results of S0 scenario (no interventions) in 2022 for (a) total phosphorus; (b) BOD and DO along Pojuca River during the best (May) and worst (September) months. Colored areas show daily pollutant loads of each municipality.

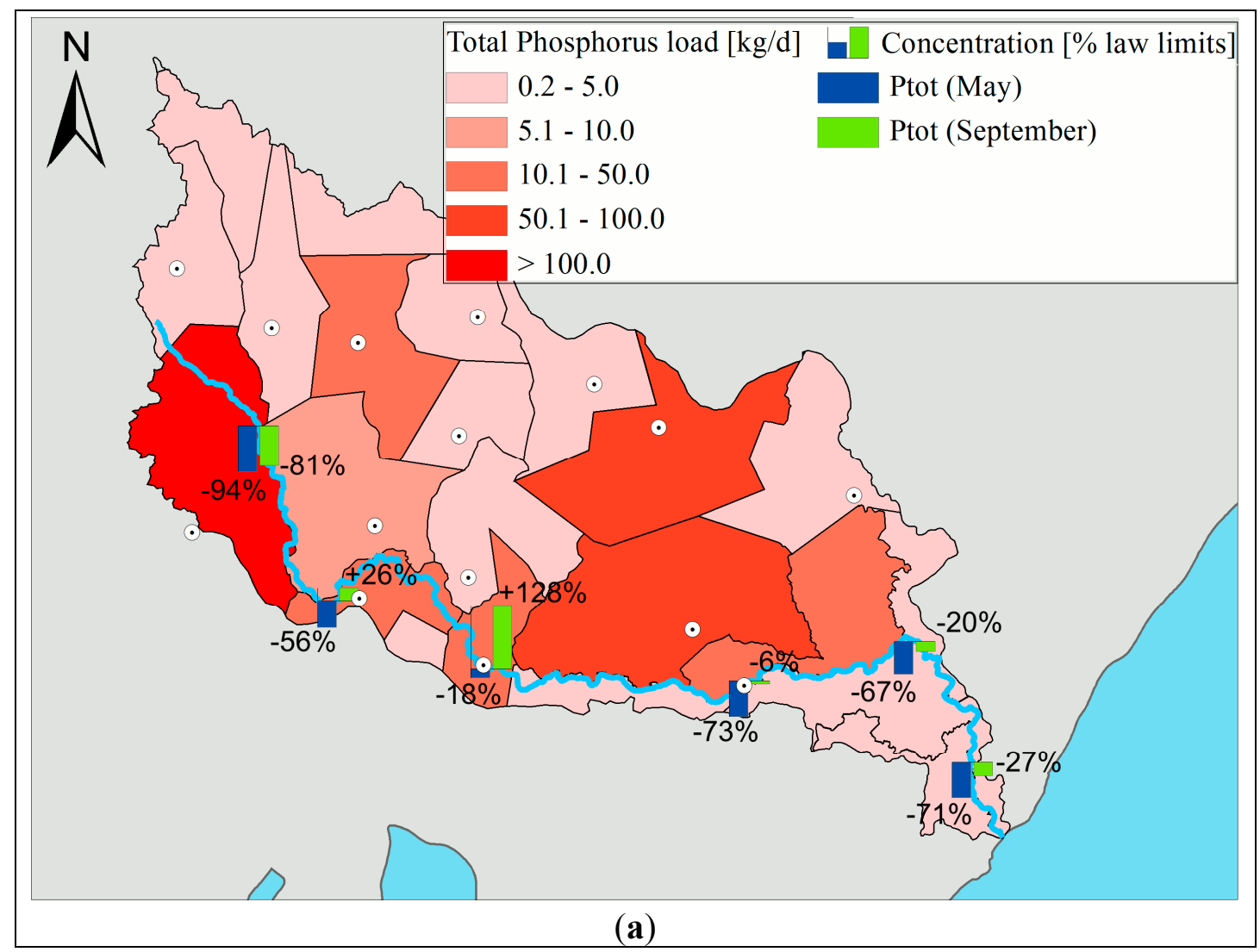


Figure 7. Cont.

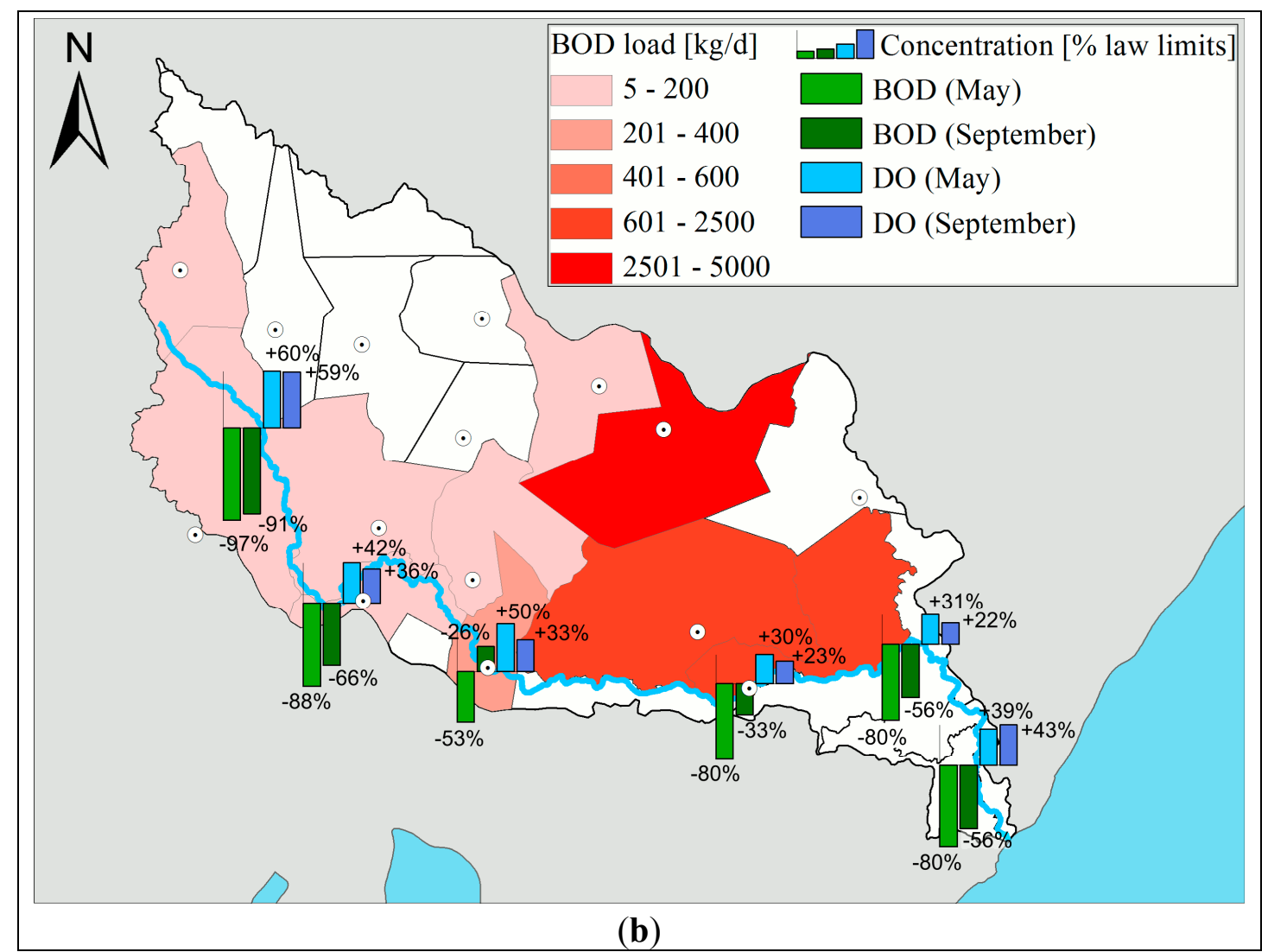

The upstream section of the river (about a quarter of the length of the river) has no pollution problems due to the scarcity of contributions from the discharged pollutants. Serious pollution problems occur further downstream (in particular between the second and third stations), especially in September, due to poor water dilution related to the low level of hydraulic load (Figure 6). DO depletion does not occur anywhere.

These results clearly indicated that corrective actions were needed. Two possible solutions were suggested and, consequently, two different scenarios were simulated (Figure 8):

- S1 scenario, based on urban sewage system coverage extension $(+30 \%$ compared to the current situation);

- S2 scenario, based both on urban sewage system coverage extension and WWTP upgradings.

Thus, considering a realistic hypothesis and considering the most common technologies, improvements were made only in major villages and towns.

There are many applied research studies aimed at identifying new technologies for improving the existing WWTPs and their performance in terms of removal [31-35]; however, in this case we made simple and realistic assumptions starting from the current state of the WWTPs in the study area. We hypothesized making improvements only in large towns and cities, according to the rules listed below (RE: removal efficiency, c: collecting system):

$$
\begin{aligned}
& \mathrm{c}_{\mathrm{ss} 2022}=\mathrm{c}_{\mathrm{s} s 2001}+30 \% \text { and } \max \left(\mathrm{c}_{\mathrm{ss} 2022}\right) \leq 100 \% \\
& \mathrm{RE}_{\text {wwtp Ptot } 2022}=\mathrm{RE}_{\mathrm{wwtp}} \text { Ptot } 2001+30 \% \text { and } \max \left(\mathrm{RE}_{\mathrm{wwtp}} \text { Ptot } 2022\right) \leq 50 \% \\
& \mathrm{RE}_{\text {wwtp BOD } 2022}=\mathrm{RE}_{\text {wwtp BOD } 2001}+30 \% \text { and } \max \left(\mathrm{RE}_{\text {wwtp BOD 2022 }}\right) \leq 90 \%
\end{aligned}
$$




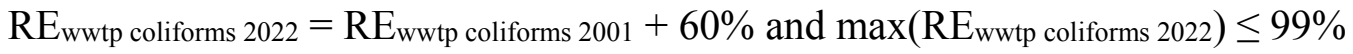
where subscripts 2001 and 2022 refer to 2001 and 2022 infrastructure status respectively [10].

Figure 8. River profile of (a) total phosphorus and (b) BOD concentrations in 2022 during the worst month (September) with different scenarios. Broken lines refer to regulation limits (Class II) [24].

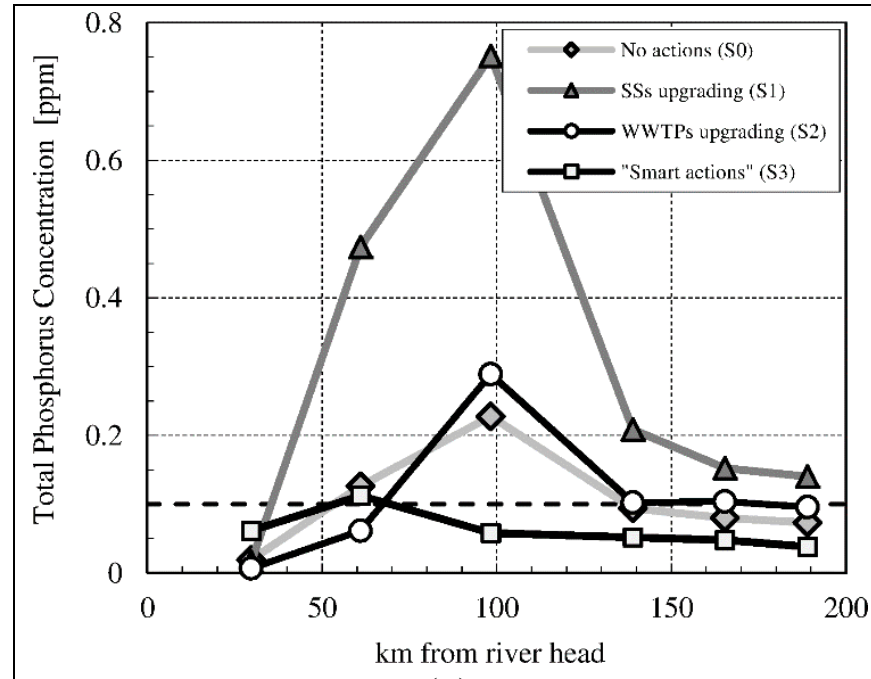

(a)

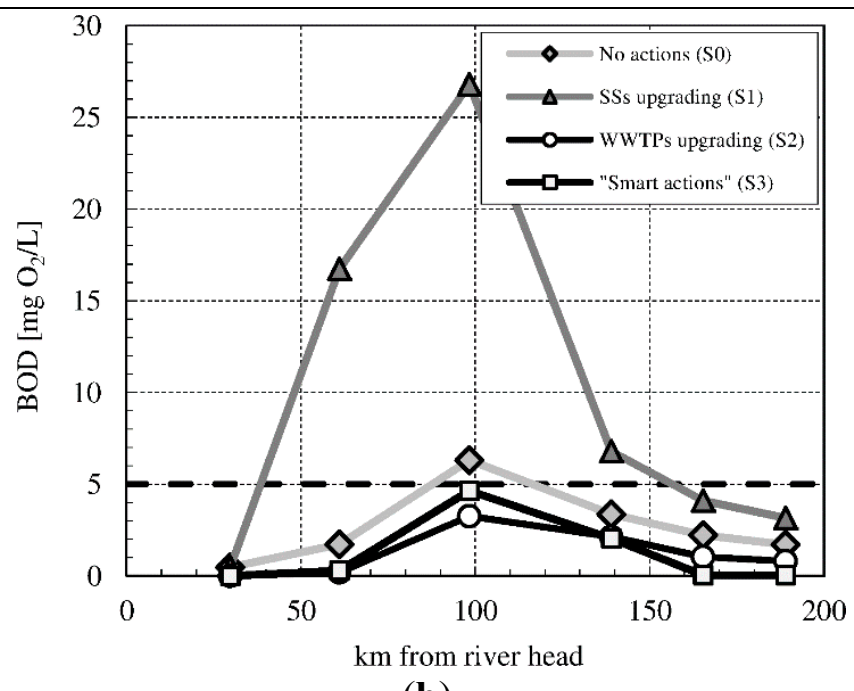

(b)

An alternative scenario (S1) provides for the extension of the sewage system coverage. This scenario is the worst case scenario, because untreated sludge is discharged directly "as it is" into the river. The combination of upgrading sewerage systems and WWTPs (S2) is in compliance with the regulations for BOD, but not for total phosphorus, considering the comparison between the concentration value and the regulation limit.

Therefore, scenario S3, based on "smart actions", was proposed. "The smart actions" are the results of a simulated debate conducted between stakeholders (e.g., municipalities, industries, actors demanding water), obviously in compliance with the regulation limits regarding water quality. The best solution focused on the complete coverage of the sewage system in the upper part of the river basin. Compliance with the regulation limits was achieved by focusing on total phosphorus load removal rather than on BOD removal. In addition to the coverage of sewerage networks, smart action entailed upgrading a number of plants, characterized by the highest pollutant loads and/or located in areas where the river and the natural environment would be particularly vulnerable.

\subsection{Salvador da Bahia Water Supply Project: Construction of the Itapecirica Reservoir}

The construction of the Itapecirica reservoir was added to all the previous simulated scenarios. According to the CEPIS method, the trophic status of the Itapecirica reservoir for S3 scenario is mesotrophic. These outcomes highlight the strong risk of eutrophication, with a serious impact on the supply of low-cost water. 


\subsection{Riverine Microhabitat Change Assessment}

The statistical analysis showed a negative trend of the discharge data ( $-10 \%$ over the last ten years), probably because of climate change (Figure $2 b$ ), in the sense that the reduction in rainfall has resulted in a reduction in the natural flow of the river. There are not enough elements to assess whether it is a temporary reduction due to the cyclical nature of the phenomena, or if climate change has led to a not temporary reduction. The RP-DSS also assesses the effects of changes in water discharge of the river microhabitats. We report an analysis of a cross-section downstream of the planned Itapecirica dam: here Characidium is the reference species. Two scenarios were examined:

a. climate change in a 20-year period, comparing 2012 and 2032 water discharge scenarios (Q2012 and $\left.\mathrm{Q}_{2032}\right)$.

b. building of the Itapecirica reservoir (hydraulic experts of the working team estimated a downstream water discharge of about $10 \mathrm{~m}^{3} / \mathrm{s}^{-1}$ in order to ensure the Salvador da Bahia water supply).

Figure 9 shows the results; in order to evaluate changes, CHSI data were normalized by 2012 CHSI.

The discharge reduction increases (up to $30 \%$ of the current situation during drought periods) the suitability of the habitat for Characidium because of its propensity to live in medium velocity and shallow water environments (Figure 3b). In contrast, simulated reservoir management generates a considerable reduction in microhabitat suitability (up to $50 \%$ of the current situation during droughts), with risks of a decrease in biodiversity in the riverine environment.

Figure 9. Behavior of composite habitat suitability index (CHSI; thick lines) due to discharge changes occurring at the cross section downstream of the Itapecirica dam. A comparison is shown between a discharge scenario for the year 2032 without the dam $\left(Q_{2032}\right)$ and discharge scenario with the dam (Qout reservoir), normalized with respect to the discharge situation in $2012\left(\mathrm{Q}_{2012}\right)$.

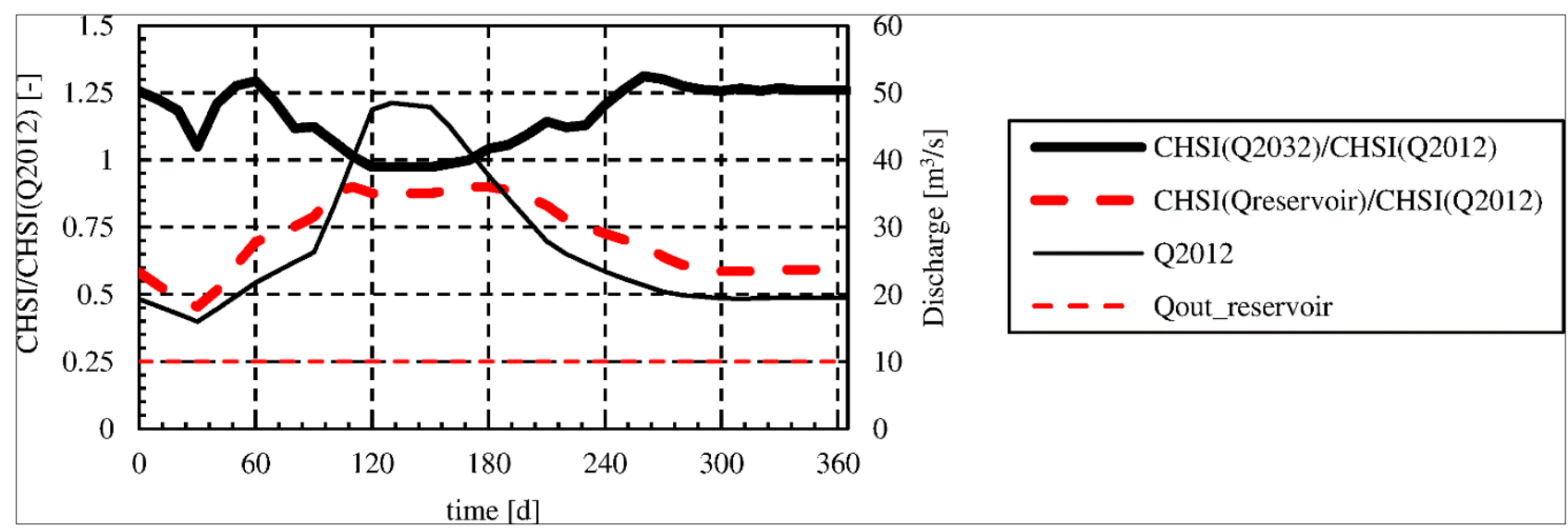

\section{Conclusions}

In our case study, a DSS (RP-DSS) was developed using a multidisciplinary approach. The aim was to draw up a plan for the sustainable management of the river basin of a major Brazilian river (State of Bahia, Brazil). This application is particularly relevant in the local context in which it was used. In fact, 
the importance of water resources, their conservation and their sustainable use, are all priorities, however making the right choices is difficult in terms of planning the use of resources.

Obviously improving the water quality of the river and its habitat is not sufficient for the sustainable resource use. In fact, the RP-DSS is only a tool to be used for assessing the implications of different solutions in terms of the quality of the watercourse. The various operational scenarios need to be identified in collaboration with stakeholders.

The DSS includes dynamic models that show the trend of the quality of the surface water and river habitats. Water quality models, calibrated by a monitoring campaign and on the basis of a hydrological model, simulated the effects of water withdrawals, the presence of a reservoir, and the management and upgrade of municipal sewer systems and WWTPs. The RP-DDS also simulates the effects that the creation of a reservoir could have in terms of the accumulation of water destined for the drinking water supply, especially in terms of the risk of eutrophication. In addition, the DSS evaluates the river water quality regarding the limits laid down by Brazilian law and assesses the compliance in relation to different scenarios assumed in the management plan. The suitability of the river microhabitat is evaluated using a sub-model which considers only reference cross-sections chosen by biologists and ichthyologists. This model is useful in cases of financial constraints and inaccessible geographical sites.

The RP-DSS was developed with the collaboration of Brazilian stakeholders (researchers, administrators, decision-makers), aimed at creating a tool for selecting and then assessing the most efficient and effective strategies aimed at sustainable development. This involves the conservation of a river habitat and the high quality of surface water without compromising the development of local communities and their economic growth. The involvement of stakeholders in the design of the DSS was extremely important. The importance of the various aspects and the functional link between the sub-models of DSS were discussed with local technicians and stakeholders. The role of stakeholders was also crucial, both during the phase of data acquisition, and with the field surveys, which during the identification of the operating scenarios. This involvement was also critical in order to increase trust and confidence in the model and in order to buy-in the results. In addition the involvement of stakeholders has served several purposes. As mentioned previously, it was necessary to better structure the DSS and to choose the smart actions, but also had an educational function, forcing technicians and decision makers, usually accustomed to working individually, to deal with only one set agenda and according to a defined working plan.

Such a goal can be achieved through so-called "Smart actions", which consist in a combination of infrastructure projects arisen from the stakeholders' face-off.

In addition, with the cooperation and development of RP-DSS, and the widespread involvement of local technicians and specialists, the project was able to exploit existing local skills and take into account local traditions and cultures.

The RP-DSS is therefore a useful tool for the rapid evaluation of interventions (OECD "Responses") aimed at mitigating the effects ("State") of social, economic and climate change scenarios ("Pressures").

The RP-DSS was set up in a visual language and is deliberately very user friendly. It consists of modules that can be easily transferred to other water basins to help decision makers and involve stakeholders in terms of the various financial and environmental issues in the problem solving process. 
In the near future, we expect to see the results of the use of the RP-DSS for planning the use of water resources in the considered basin and, if successful, we will then transfer the experience to other geographical areas.

\section{Acknowledgments}

The author wishes to thank Massimo Raboni, Sabrina Copelli, Mentore Vaccari, Sabrina Sorlini and Giordano Urbini for their important help.

\section{Conflicts of Interest}

The author declares no conflict of interest.

\section{References}

1. Caminiti, J.E. Catchment modelling-A resource manager's perspective. Environ. Model. Softw. 2004, 19, 991-997.

2. Di Mauro, C.; Bouchon, S.; Torretta, V. Industrial Risk in the Lombardy Region (Italy): What people perceive and what are the gaps to improve the Risk Communication and the Participatory Processes. Chem. Eng. Trans. 2012, 26, 297-302.

3. Oxley, T.; McIntosh, B.S.; Winder, N.; Mulligan, M.; Engelen, G. Integrated modelling and decision-support tools: A Mediterranean example. Environ. Model. Softw. 2004, 19, 999-1010.

4. Berlekamp, J.; Lautenbach, S.; Graf, N.; Reimer, S.; Matthies, M. Integration of MONERIS and GREAT-ER in the decision support system for the German Elbe river basin. Environ. Model. Softw. 2007, 22, 239-247.

5. Assaf, H.; Saadeh, M. Assessing water quality management options in the Upper Litani Basin, Lebanon, using an integrated GIS-based decision support system. Environ. Model. Softw. 2008, 23, 1327-1337.

6. Maia, R.; Silva, C. DSS application at a river basin scale, taking into account water resources exploitation risks and associated costs: The Algarve Region. Desalination 2009, 237, 81-91.

7. Holguin, J.E.; Everaert, G.; Boets, P.; Goethals, P.L.M.; Alberto, G. Development and application of an integrated ecological modelling framework to analyze the impact of wastewater discharges on the ecological water quality. Environ. Model. Softw. 2013, 48, 27-36.

8. Jähnig, S.C.; Kuemmerlen, M.; Kiesel, J.; Domisch, S.; Cai, Q.; Schmalz, B.; Fohrer, N. Modelling of riverine ecosystems by integrating models: Conceptual approach, a case study and research agenda. J. Biogeogr. 2012, 39, 2253-2263.

9. Lautenbach, S.; Berlekamp, J.; Graf, N.; Seppelt, R.; Matthies, M. Scenario analysis and management options for sustainable river basin management: Application of the Elbe DSS. Environ. Model. Softw. 2009, 24, 26-43.

10. Collivignarelli, C.; de Felice, V.; di Bella, V.; Sorlini, S.; Torretta, V.; Vaccari, M. Assessment of sanitary infrastructures and polluting loads in Pojuca River (Brazil). Water Pract. Technol. 2012, doi:10.2166/wpt.2012.044. 
11. Vaccari, M.; Torretta, V.; Collivignarelli, C. Effect of improving environmental sustainability in developing countries by upgrading solid waste management techniques: A case study. Sustainability 2012, 4, 2852-2861.

12. Torretta, V.; Conti, F.; Leonardi, M.; Ruggieri, G. Energy recovery from sludge and sustainable development: A tanzanian case study. Sustainability 2012, 4, 2661-2672.

13. Torretta, V. PAHs in wastewater: Removal efficiency in a conventional wastewater treatment plant and comparison with model predictions. Environ. Technol. 2012, 33, 851-855.

14. Santana dos Santos, A.; Soares, L.; Marcovaldi, M.A.; da Silveira Monteiro, D.; Giffoni, B.; de Pádua Almeida, A. Avaliação do Estado de Conservação das Tartarugas Marinhas, Caretta caretta Linnaeus, 1758 no Brasil (Assessment of the conservation status of sea turtle, Caretta caretta Linnaeus, 1758 in Brazil). Biodivers. Bras. 2011, 1, 3-11.

15. CRA-Centro de Recursos Ambientais. Rumo a um Desenvolvimento Sustentável: Indicadores Ambientais; CRA - Secretaria Municipal de Planejamento: Salvador, Brazil, 2002. (In Portuguese)

16. Magrini, A.; Fraga, I.; Santos, M. Environmental Management of Watersheds in Brazil: A New Approach for Environment and Water Resources Management. In New Trends in Water and Environmental Engineering for Safety and Life; Maione, U., Lehto, M.B., Monti, R., Balkema, A.A., Eds.; Balkema: Rotterdam, The Netherlands, 2000.

17. Stalnaker, C.; Lamb, B.L.; Henriksen, J.; Bovee, K.; Bartholow, J.M. The Instream Flow Incremental Methodology: A Primer for IFIM; Report 29; U.S. Department of the Interior: Washington, DC, USA, 1995.

18. Britski, H.A.; Garavello, J.C. Redescription of Parotocinclus bahiensis. Zootaxa 2009, 2143, 59-67.

19. Oyakawa, O.T. Catalogo dos tipos de peixes recentes do Museu de Zoologia da USP (São Paulo University Zoology Museum recent fishes Catalogue). I. Characiformes (Teleostei: Ostariophysi). Pap. Avuls. Zool. 1998, 39, 443-507.

20. McMahon, T.E. Habitat Suitability Index Models: Creek Chub. Fish and Wildlife Service; Report FWS/OBS-82/10.4; Department of the Interior: Washington, DC, USA, 1982.

21. Chow, V.T.; Maidment, D.R.; Mays, L.W. Applied Hydrology; McGraw-Hill: New York, NY, USA, 1988.

22. Chapra, S.; Pelletier, G.; Tao, H. QUAL2K: A Modeling Framework for Simulating River and Stream Water Quality, Version 2.11. In Documentation and Users Manual; Tufts University: Medford, MA, USA, 2008.

23. Thomann, R.V.; Mueller, J.A. Principles of Surface-Water Quality Modelling and Control; Harper \& Row: New York, NY, USA, 1987.

24. CONAMA-Ministério do Meio Ambiente e Conselho Nacional do Meio Ambiente. Resolução $n$. 357 de 17 de Março de 2005; Ministério do Meio Ambiente: São Paulo, Brazil, 2005. (In Portuguese)

25. Salas, H.J.; Martino, P. A simplified phosphorus trophic state model for warm-water tropical lakes. Water Resour. 1991, 25, 341-350.

26. Gordon, N.D.; McMahon, T.A.; Finlayson, B.L. Stream Hydrology, an Introduction for Ecologists; John Wiley \& Sons: Chichester, UK, 1992.

27. USGS-U.S.Geological Survey. PHABSIM for Windows-User's Manual and Exercises; Open File Report 01-340; USGS—U.S.Geological Survey: Reston, VA, USA, 2001. 
28. CETESB. Companhia de Tecnologia de Saneamento Ambiental 2001. In Relatório de Qualidade das Águas Interiores do Estado de São Paulo 2000 (Report about Freshwater Quality in São Paulo State 2000); Ministério do Meio Ambiente: São Paulo, Brazil, 2001. (In Portuguese)

29. Von Sperling, M. Introdução à Qualidade das Água e ao Tratamento de Esgotos (Introduction to Water Quality and Wastewater Treatment); $3^{\circ}$ edição; DESA UFMG: Belo Horizonte, Brazil, 2005; Volume 1.

30. UNESCO - United Nations Educational, Scientific and Cultural Organization. Manual on Drainage in Urbanized Areas vol. 1, Planning and Design of Drainage Systems; UNESCO Press: New York, NY, USA, 1987.

31. Joss, A. Are we about to upgrade wastewater treatment for removing organic micropollutants? In Neptune workshop: Technical Solutions for Nutrient and Micropollutants Removal in WWTPs; Université Laval: Québec, QC, Canada, 25-26 March 2010.

32. Luciano, A.; Viotti, P.; Mancini, G.; Torretta, V. An integrated wastewater treatment system using a BAS reactor with biomass attached to tubular supports. J. Environ. Manag. 2012, 113, 51-60.

33. Torretta, V.; Urbini, G.; Raboni, M.; Copelli, S.; Viotti, P.; Luciano, A.; Mancini, G. Effect of powdered activated carbon to reduce fouling in membrane bioreactors: A sustainable solution. Case study. Sustainability 2013, 5, 1501-1509.

34. Raboni, M.; Torretta, V.; Viotti, P.; Urbini, G. Pilot experimentation with complete mixing anoxic reactors to improve sewage denitrification in treatment plants in small communities. Sustainability 2014, 6, 112-122.

35. Torretta, V.; Ragazzi, M.; Trulli, E.; de Feo, G.; Urbini, G.; Raboni, M.; Rada, E.C. Assessment of biological kinetics in a conventional municipal WWTP by means of the oxygen uptake rate method. Sustainability 2014, 6, 1833-1847.

(C) 2014 by the author; licensee MDPI, Basel, Switzerland. This article is an open access article distributed under the terms and conditions of the Creative Commons Attribution license (http://creativecommons.org/licenses/by/4.0/). 